\title{
THE ECONOMIC APPROACH TO ANALYZING THE FINANCIAL POSITION OF HOUSING AND UTILITIES ENTERPRISES"
}

\author{
Tat'yana Yu. SEREBRYAKOVA a, , Aleksandr S. ANISIMOV ${ }^{\mathrm{b}}$
}

\author{
${ }^{a}$ Cheboksary Institute of Cooperation, Branch of Russian University of Cooperation, \\ Cheboksary, Chuvash Republic, Russian Federation \\ tserebryakova@rucoop.ru \\ https://orcid.org/0000-0003-3823-8447 \\ ${ }^{\mathrm{b}}$ Cheboksary Institute of Cooperation, Branch of Russian University of Cooperation, \\ Cheboksary, Chuvash Republic, Russian Federation \\ anisimov_alexander_sergeevich@mail.ru \\ ORCID: not available \\ - Corresponding author
}

\section{Article history:}

Article No. 399/2019

Received 3 June 2019

Received in revised form

10 June 2019

Accepted 12 June 2019

Available online

25 December 2019

JEL classification: M49

\begin{abstract}
Subject Housing and utilities is a crucial industry in any economic system, since it serves people's needs. However, the reality of the market economy brings the crisis of such enterprises to the surface. Most of them are on the brink of bankruptcy, mainly due to difficulties accessing financial resources, constantly growing cost of supplies, energy, ineffective financial management, etc.

Objectives The study provides the rationale for the financial analysis of housing and utilities enterprises and sets out guidelines for enhancing their performance.

Methods We applied general methods of research, statistical and comparative methods and financial analysis. Based on the systems approach and logic generalization, we streamline prevailing views on key challenges to such enterprises. Having synthesized the findings and conducted modeling, we set out recommendations for enhancing the performance of housing and utilities enterprises.

Results The financial position of housing and utilities enterprises should be analyzed in line with the sectoral specifics.

Conclusions and Relevance Housing and utilities has its own distinctions, such as the social focus, high obsolescence of fixed assets, dependency on governmental aid, regional may be used in their research, accounting and financial practices.
\end{abstract} Keywords: financial analysis, and climate differences, tariff regulation. The factors should be considered as part of the housing and utilities, financial financial analysis and key regulatory targets of the financial position in such enterprises. position, financial management, efficiency

The editor-in-charge of this article was Irina M. Vechkanova

The authorized translation by Irina M. Vechkanova

Please cite this article as: Serebryakova T.Yu., Anisimov A.S. The Economic Approach to Analyzing the Financial Position of Housing and Utilities Enterprises. Digest Finance, 2019, vol. 24, iss. 4, pp. 379-387.

https://doi.org/10.24891/df.24.4.379

Socio-economic reforms in Russia aim to create the market of housing and utilities services as one of the most complicated missions. The housing and utilities have become a complex system made

"For the source article, please refer to: Серебрякова Т.Ю., Анисимов А.С. Экономический подход к анализу финансового состояния на предприятиях жилищно-коммунальной сферы // Международный бухгалтерский учет. 2019. Т. 22. № 6.

C. 636-649. URL: https://doi.org/10.24891/ia.22.6.636 of multiple sectors and influenced by the administrative and central control since its inception. Currently, management companies are the main driving force in the sector, namely homeowner association, housing cooperatives, management companies that are directly in charge of managing an apartment block. 
The mix of housing and utilities services does not completely satisfy existing requirements, including financial and economic ones. Nowadays Russia's housing and utilities sector demonstrates ineffective mechanisms of economic management, disparity of the volume and quality of services, irrational and unbalanced development, threat of financial failure due to uncertainty, etc. [1].

The financial health, operational stability, professional competence of management companies determine the financial position of resource providers and contractors, uninterrupted operation of the overall housing and utilities infrastructure and ensures the appropriate quality of housing and utilities services that meet the existing quality standards and transparent pricing principle.

The housing and utilities sector has financial and economic distinctions. First, its services cannot be substituted, that is, consumers cannot opt for another service instead or refuse to use it or reduce their consumption even when respective tariffs significantly go up. Second, they should operate in an uninterrupted and reliable manner. Third, such enterprises are not totally free to set up prices for housing and utilities services. It means that the cost of housing and utilities services they deliver depends on their production costs resulting from the composition and reasonable amount of profit [2].

The effectiveness of managerial decisions is a critical matter, especially considering risks and uncertainty of the external environment. They influence the financial position of entities, including those operating in housing and utilities. Therefore, it is reasonable to monitor the financial health by conducting the financial analysis of housing and utilities entities so as to detect challenging aspects of their performance.

Table 1 shows the specifics of the housing and utilities sector.

It is worth mentioning that sectoral distinctions of housing and utilities entities influence key characteristics of their financial position, notwithstanding that it is assessed with the same indicators of availability, allocation, and use of financial resources. Nowadays, the financial analysis provides analytical information to make managerial decisions pursuing more stable and efficient corporate performance. Hence, the financial analysis serves for evaluating the financial position, financial sustainability of an entity exposed to uncertainty and financial risks.

As users of financial statements have certain needs and expectations and the financial position should be managed correspondingly, a nuanced approach is applied with regard to internal and external parties initiating the analysis. Thus, there is the internal and external financial analysis [3].

As wee see it, a financial analysis is the process of examining the financial position and key performance indicators to find and consolidate capabilities for raising the market value and ensure a sustainable growth [4].

The management should conduct the internal financial analysis to guide the company. It aims to streamline and leverage monetary proceeds and allocate equity and borrowings so as to ensure proper operations of the housing and utilities company, derive as much profit as possible and monitor risks of the above partial tasks.

Being assessed through their financial statements, entities are analyzed externally by would-be and existing investors, suppliers of tangible and financial resources, controlling authorities. Financial analysis pursues different goals, as every user tries to find what interests him or her in particular. For example, evaluating the feasibility of investment in the analyzable company, understanding the probability of bankruptcy or deciding on large supplies on prepayment terms and assessing the company's solvency respectively. It goes without saying that users intend to mitigate their risks of financial losses in all the above situations.

There are different approaches and techniques to performing the financial analysis of a company. Multiple key approaches have some common and different features, which should be taken into consideration. Consequently, a variety of techniques complicates a choice, since users need to understand which technique would be more beneficial to analyze the financial position under different circumstances, including situations with housing and utilities companies.

Proposed by A.D. Sheremet and E.V. Negashev, the financial analysis technique is mostly designated for internal users, representing a 
comprehensive analysis of corporate performance. As part of the financial analysis, analysts measure financial results and comprehensively evaluate corporate efficiency $[5,6]$. The financial analysis of the financial position includes:

- a structural analysis of assets and liabilities;

- an analysis of financial sustainability (autonomy), which depends on the satisfactory and unsatisfactory composition of the balance sheet, thus allowing to utilize financial results of corporate performance;

- liquidity analysis focusing on the amount needed to extinguish liabilities with available assets, with the time required to convert them into cash (asset liquidity) directly indicates the time for settling the liabilities;

- solvency analysis, i.e. the ability of housing and utilities entities to fulfill their payment obligations to suppliers, repay loans and borrowings (creditworthiness) and make other payments;

- cash flows analysis revealing changes in the financial position due to changes in cash flows, which allows to forecast the future cash flows and outflows.

However, examining the financial standing, analysts should primarily check equity and factors influencing its dynamics, review working assets and their sufficiency.

As per the technique proposed by A.N. Gavrilova and A.A. Popov, entities should conduct the overall qualitative analysis of financial reporting and analysis of ratios:

- analysis of liquidity and solvency;

- analysis of financial sustainability;

- analysis of business activity;

- analysis of profitability.

It is reasonable to assess financial ratios to understand the financial health of a housing and utilities entity. Besides, financial statements should be analyzed, including the composition and dynamics of assets and, correspondingly, their sources. Entity should also evaluate the liquidity of its balance sheet and conduct the qualitative (factor) analysis of financial results.

In the analysis of the financial position in housing and utilities, analytical procedures should be chosen in line with methodological considerations.

E.A. Markar'yan and G.P. Gerasimenko proposed their technique for analyzing the property and sources of financial resources. They suggest focusing on the following aspects [7]:

- analysis of assets and liabilities in terms of content and composition;

- analysis of financial sustainability and autonomy;

- analysis of solvency and liquidity;

- analysis of financial results;

- financial forecasting.

In his technique V.V. Bocharov relies upon approaches proposed by A.I. Kovalev. It provides for two steps of the financial standing analysis [8]:

- quick analysis of financial and business operations;

- thorough financial analysis.

Quick analysis is intended to assess the financial health of an entity in a prompt, illustrative and reliable manner [9]. Quick analysis should be split in three steps:

- preliminary step;

- pre-review of financial statements;

- analysis of financial statements.

At the first step, users decide to analyze financial statements and confirm its reliability. The auditor report is a good source of such information.

At the second step, users examine notes to financial statement so as to evaluate the environment that the entity operates in during the reporting period, and trace key tendencies of its performance indicators.

At the third step, users make a comprehensive view of financial and business operations in order 
to study sources of corporate proceeds, their allocation and use.

Quick analysis shows whether further analysis is needed, which is called to evaluate the financial sustainability, cash flows, business and market activities. It is worth mentioning that a thorough analysis is meant to describe the property and financial position in a detailed manner, evaluate the current financial results and forecast the future developments.

Professor N.P. Lyubushin suggests that the following steps should be made [10]:

- analyzing changes in the composition and structure of corporate assets;

- analyzing changes in the composition and structure of corporate liabilities;

- evaluating the corporate solvency;

- assessing the financial sustainability;

- analyzing the business activity spotlighting indicators below:

- average monthly revenue, percentage of cash in revenue, average headcount;

- metrics of solvency and financial sustainability;

- efficiency of working capital use, respective indicators;

- profitability metrics;

- production intensification metrics;

- investment indicators;

- fulfillment of liabilities due to different levels of budgets and governmental extrabudgetary funds;

- evaluation of the corporate ability to repay debts;

- bankruptcy analysis.

Following the above steps, users make a comprehensive conclusion on the financial health of the entity, conducting a follow-up forecast, summarizing what modifications should be made in the balance sheet. Subsequently, users can report on the future solvency and financial sustainability of the entity [11].
Considering the above five techniques, the most appropriate one should be selected for housing and utilities entities so that they could assess their financial standing as accurately and adequately as possible. Doing so, they will ensure the proper management by coordinating all factors of creating housing and utilities services and departments and segregating their duties respectively.

Considering the aspects and steps of the financial analysis, we point out some common ones, such as the analysis of assets and liabilities and their composition, solvency, financial autonomy (sustainability, stability), business activity, liquidity. Therefore, we believe that the aspects and indicators will underlie any analysis of the financial position of housing and utilities entities.

The technique proposed by A.N. Gavrilova and A.A. Popov seems most comprehensive. We suggest relying upon the technique, though slightly modifying it. There will be two fundamental blocks, which include basic and additional aspects of the financial position analysis. This will facilitate a comprehensive evaluation so as to examine all the aspects of the financial position.

As for housing and utilities, the methodological analysis of the financial position, as proposed by A.N. Gavrilova and A.A. Popova, will rest on two blocks:

- overall qualitative analysis of financial statements:

- evaluating the composition and dynamics of property and its sources;

- qualitative analysis of financial results;

- analysis of ratios to evaluate the financial position:

- liquidity and solvency;

- financial sustainability;

- business activity.

Assessing the housing and utilities entity as part of the above blocks, users will get a comprehensive understanding of its current economic situation. Some adjustments would be advisable at the step so as to rearrange the sequence of analytical computations as proposed by A.N. Gavrilova and A.A. Popov. In our 
opinion, financial results and profitability should be analyzed separately from the financial position, making it another step of the financial analysis, that is, excluding it from the technique. Besides, we suggest the analysis of net assets should be attributed to the qualitative analysis of financial statements. Hence, the financial position of housing and utilities entities will be analyzed as follows:

- overall qualitative analysis of financial statements:

- the composition and dynamics of property and its sources;

- net assets;

- the analysis of ratios to evaluate the financial position:

- liquidity and solvency;

- financial sustainability;

- business activity.

The comparative analytical balance sheet should be a cornerstone for examining the composition, dynamics of corporate property and its sources. It contains indicators that can be used for a horizontal (trend) and vertical analysis. As part of the overall qualitative analysis, users prepare an aggregate balance sheet, analyze the composition and dynamics of assets, focusing on non-current and current assets, accounts receivable, composition and dynamics of capital, accounts payable and net assets [12].

The financial statement analysis and financial ratios reveal the financial health of an entity. However, it is important to remember that target ratios do not always fit some industry perfectly due to its sectoral distinctions. Such ratios should accommodate for such specifics. They may vary significantly as the size of entities and their environment are not identical [13].

The financial statement analysis is not that difficult provided users have all relevant information. It does not take much time to do calculations or investigate some strategic details of performance.

According to E.A. Markar'yan, G.P. Gerasimenko, S.E. Markar'yan, a financial analysis may have the following formats:
- quick analysis providing the general understanding of the financial position with reference to financial statements;

- comprehensive financial analysis allowing to comprehensively evaluate the financial position with reference to financial statements, some itemized sections, analytical accounting data and findings of independent audits, etc.;

- financial analysis as part of the overall evaluation of business processes giving a comprehensive view of all business aspects, such as production, procurement, marketing, distribution, management, finance, human resources, etc.;

- dedicated financial analysis for detecting a key financial difficulty, such as leveraging the debt with reference to the main forms of financial statements and items relating to the issue;

- regular financial analysis for ensuring the effective management of corporate finance within definite timelines, quarterly or monthly and summing up specifically processed results of a comprehensive financial analysis [14].

On the other hand, a financial analysis can have another classification.

1. Retrospective analysis observes how indicators change over time in comparison with the previous period. Conducting the retrospective analysis, users identify business development trends, risks, threats or positive trends. It helps evaluate the efficacy of management, including the effect on the financial position.

2. Variance analysis serves for assessing the efficacy of financial position management, comparing planned and actual indicators. It helps determine how executives perform corporate plans.

3. Horizon analysis estimates indicators of the financial position so as to identify risks and opportunities for setting strategic and tactical goals and plans, including financial ones [15].

A financial analysis of the housing and utilities sector should cover the following aspects:

- financial position as described above;

- return (profitability);

- bankruptcy risk. 
The construction and use of equity and borrowings, respective ratios, ratio of debtors and creditors, generation of income and ultimate financial result are what influences optimal (normal) values of financial ratios.

Currently, entities operating in the Russian housing and utilities sector face many economic troubles, such as:

- underdeveloped utilities engineering systems to satisfy growing public needs;

- unequal distribution of capacities, which causes the ineffective usage of financial resources;

- very outdated and obsolete facilities;

- a lack of mechanisms for collecting and processing the information on the consumption of housing and utilities resources, and nonexistent database of residents;

- ineffective usage of natural resources, causing their loss, including heat and electric power during its production and supply to consumers;

- low efficiency of financial management and predominance of administrative methods.

We should mention circumstances that influence the statutory value of financial ratios, such as:

- uneven allocation of VAT across departments and levels of housing and utilities entities;

- a lack of sufficient working resources to continue operations, expensive borrowings needed to replenish sources of finance, and difficult access to them;

- tariff regulation and tough control, biased and understated cost of housing and utilities services, which impedes a 100-percent recovery of actual delivery costs through prices for housing and utilities services;

- a lack of non-current assets or their low value recognized in the balance sheet, which immediately affects the composition of the balance sheet and some financial ratios, though there are other explicit signs of crisis [16].

Besides, the housing and utilities sector exists for social purposes, being sensitive to any price rise, notwithstanding undeniable reasons for setting fair prices for public utilities. The poor quality of such services makes the public deny initiatives of setting reasonable housing and utilities tariffs that would be commensurate to the cost of the services.

In our opinion, after a financial position analysis is performed, entities should primarily make respective decisions for cushioning adverse consequences that affect housing and utilities entities. For instance, we can make several suggestions for mitigating financial risks and making the financial analysis more optimistic:

- timely financial analysis and ongoing control and monitoring of the probability of adverse scenarios;

- raising the quality and transparency standards of financial reports in housing and utilities;

- mapping possible risks and action plan to eliminate them;

- acquiring skills and knowledge to use various methods of financial analysis;

- improving the quality of services, thus reducing risk events;

- bringing the public literacy in data use to higher levels;

- ensuring the personnel advancement so as to avoid financial errors in the future;

- implementing innovations to deliver housing and utilities services, which incidentally helps increase the efficiency of financial and business performance [17].

A financial analysis is very relevant to housing and utilities. The financial analysis technique directly depends on the specifics of the sector wherein entities operate. Nowadays, it is of national importance to increase the efficiency of housing and utilities. Entities should necessarily form their financial analysis technique. It provides for inter alia scientifically proven and statutory values of financial ratios and other key performance indicators of housing and utilities entities.

As its main purpose, a financial analysis evaluates the quality of financial statements. If reports are properly prepared, the information can be used reliably to compute financial indicators, make investment decisions and financial plans [18]. 
Having studied and gleaned financial indicators that directly determine the probability of bankruptcy in housing and utilities, we selected the ones below:

- equity and provisions to total assets ratio (financial autonomy);

- working-assets-to-total-equity ratio;

- working-capital-to-current-assets ratio;

- liquidity ratio;

- ratios of highly marketable current assets to current liabilities and liquidity in case of fundraising.

Classification trees were used to assess new values of the ratios and their adjustments for management companies working in housing and utilities. A certain class of stability is assigned to an entity in line with threshold values of the above ratios.

Housing and utilities entities may be ranked by the extent they comply with statutory indicators. Such ranking may used by the following institutions:

- governmental authorities to monitor and analyze the financial position of housing and utilities entities. For example, rankings of management companies;

- management companies which directly operate apartment blocks in order to assess and control their own position;

- self-regulatory organizations of housing and utilities sector to make up compensation funds.

As the study reveals, the ratios below and respective values should be considered normal for housing and utilities entities.

1. Equity-to-total-assets ratio reflecting the percentage of corporate assets which settle equity finance. It is normally 0.5 . Based on our computations, it should optimally be 0.7 and more. In this case, housing and utilities entities will be able to keep a flexible financial policy for their equity.

2. Working-assets-to-total-equity ratio reflecting the ability of an entity to maintain its working capital. It normally ranges from 0.2 to 0.5 . In housing and utilities, it may be from 0.4 up to 0.7 to evidence the financial independence of a management company, which is able to quickly retrofit its fixed assets.

3. Working-capital-to-current-assets ratio reflecting the percentage of working capital financed with equity. It is normally 0.1 . Our computations shows a range of 0.4 to 0.7 , which indicates a sufficient amount of working capital. The financial risk is as low as possible.

4. Liquidity ratio reflecting the entity's ability to repay current liabilities with its working capital. It is normally 2 . In the analyzable companies, it was measured as much as 1-1.6, meaning that housing and utilities entities demonstrate a good liquidity.

5. Highly marketable assets to current liability ratio showing the possibility to fulfill current liabilities with the most liquid and marketable assets. Its statutory value is 0.7-1. In our computations for housing and utilities, we set 1 and more, with management companies remaining solvent.

6. The ratio of liquidity in case of fundraising reflecting the extent to which corporate solvency depends on tangible stocks in terms of fundraising to repay current liabilities. IT is usually from 0.5 to 0.7 . The housing and utilities sector should have a normal value exceeding 1 , which will indicate their high solvency and a reduction in the risk of financial loss.

We believe that the above values should accommodate for the specifics of the housing and utilities sector, thus allowing regulators to control financial and business operations of entities. In the mean time, management companies can timely detect factors challenging their financial position, and make effective managerial decisions to streamline everyday operations. Such steps will contribute to the quality of public utilities.

Therefore, a financial analysis will be more effective in the housing and utilities sector if entities undertake to reduce the impact of risk factors on their performance in order to ensure the financial recovery of the sector and make it more lucrative for investors. 
Table 1

Comparative description of Housing and Utilities segments

\begin{tabular}{lll}
\hline Metrics & Housing & Utilities \\
\hline Market niche & Housing properties & $\begin{array}{l}\text { Housing properties, administrative and } \\
\text { production facilities }\end{array}$ \\
\hline Specifics of services & $\begin{array}{l}\text { High consumption of resources and high } \\
\text { labor intensity of services, a significant } \\
\text { prevalence of tangible costs in } \\
\text { comparison with payroll funds }\end{array}$ & $\begin{array}{l}\text { High ratio of current assets to revenue and } \\
\text { energy consumption of service production, and, } \\
\text { therefore, overrun of energy consumed and } \\
\text { depreciation charges }\end{array}$ \\
$\begin{array}{l}\text { The composition of } \\
\text { fixed assets used for } \\
\text { production }\end{array}$ & $\begin{array}{l}\text { The prevalence of passive fixed assets } \\
\text { used for production }\end{array}$ & $\begin{array}{l}\text { The prevalence of active fixed assets used for } \\
\text { production }\end{array}$ \\
\hline Tariff regulation & Tariffs are set by home owners & $\begin{array}{l}\text { Tariffs are set by regional power companies and } \\
\text { local authorities }\end{array}$ \\
\hline
\end{tabular}

Source: Authoring based on materials referred to herein [19]

\section{References}

1. Alferov V.N. [Modeling of managerial analysis in housing and utilities]. Upravlencheskii uchet $=$ Management Accounting Journal, 2014, no. 12, pp. 23-32. (In Russ.)

2. Kolokolova E.O. [State information system as a means of monitoring and improving the efficiency of activity of housing and communal services: Legal aspect]. Vestnik Rossiiskogo universiteta kooperatsii $=$ Bulletin of Russian University of Cooperation, 2018, no. 1, pp. 124-128. (In Russ.)

3. Berdnikova L.F., Al'debeneva S.P. [Financial analysis: The Concept and key methods]. Molodoi uchenyi = Young Scientist, 2014, no. 1, pp. 330-338. URL: https://moluch.ru/archive/60/8847/ (In Russ.)

4. Vakhrushina M.A. [Contents and procedure for preparing of consolidated financial statements]. Mezhdunarodnyi bukhgalterskii uchet = International Accounting, 2011, no. 13, pp. 15-21. URL: https://cyberleninka.ru/article/v/soderzhanie-i-protsedury-sostavleniya-konsolidirovannoyfinansovoy-otchetnosti (In Russ.)

5. Negashev E.V. [Application of simulation balance sheet models in analysis of financial state of company]. Audit i finansovyi analiz = Audit and Financial Analysis, 2011, no. 6, pp. 167-175. (In Russ.)

6. Sheremet A.D. [Auditing and analysis of business performance]. Auditorskie vedomosti $=$ Audit Journal, 2007, no. 5, pp. 64-68. (In Russ.)

7. Markar'yan E.A. [Issues of analyzing the financial stability, solvency and liquidity of profitmaking entities]. Uchet $i$ Statistika = Accounting and Statistics, 2004, no. 1, pp. 92-97. (In Russ.)

8. Bocharov V.V., Kulebakina L.E. [Practice operational financial planning in small enterprises of Orel Region]. Audit i finansovyi analiz = Audit and Financial Analysis, 2011, no. 4, pp. 377-383. (In Russ.)

9. Khriplivyi F.P., Khriplivyi A.F. [Comparative analysis of methods of an estimation of the financial condition of a company]. Politematicheskii setevoi elektronnyi nauchnyi zhurnal Kubanskogo gosudarstvennogo agrarnogo universiteta, 2012, no. 81. (In Russ.)

URL: http://ej.kubagro.ru/2012/07/pdf/21.pdf 
10. Lyubushin N.P., Babicheva N.E., Galushkina A.I., Kozlova L.V. [Analysis of methods and models of the evaluation of the financial stability of the organizations]. Ekonomicheskii analiz: teoriya $i$ praktika = Economic Analysis: Theory and Practice, 2010, no. 1, pp. 3-11.

URL: https://cyberleninka.ru/article/v/analiz-metodov-i-modeley-otsenki-finansovoyustoychivosti-organizatsiy (In Russ.)

11. Gordeeva O.G., Serebryakova T.Yu. [On the impact of IFRS on results of financial analysis of organizations]. Mezhdunarodnyi bukhgalterskii uchet = International Accounting, 2017, vol. 20, iss. 22, pp. 1288-1303. (In Russ.) URL: https://doi.org/10.24891/ia.20.22.1288

12. Bogatyrev S.Yu. [New models for analysis of the reporting of organizations]. Mezhdunarodnyi bukhgalterskii uchet = International Accounting, 2018, vol. 21, no. 2, pp. 124-137. (In Russ.) URL: https://doi.org/10.24891/ia.21.2.124

13. Brealey R.A., Myers S.C., Marcus A.J. Fundamentals of Corporate Finance. McGraw-Hill, 2001, p. 650 .

14. Rizoev F.U. [Classification of methods of assessing the financial condition commercial organizations]. Ekonomika i biznes: teoriya i praktika $=$ Economy and Business: Theory and Practice, 2015, no. 10, pp. 117-121. URL: https://cyberleninka.ru/article/v/klassifikatsiyametodov-otsenki-finansovogo-sostoyaniya-kommercheskih-organizatsiy (In Russ.)

15. Savitskaya G.V. [The technique for assessing the operating and financial risks in business]. Ekonomicheskii analiz: teoriya i praktika = Economic Analysis: Theory and Practice, 2007, no. 16, pp. 44-52. URL: https://cyberleninka.ru/article/v/metodika-otsenki-urovnyaoperatsionnogo-i-finansovogo-strukturnogo-riska-v-predprinimatelskoy-deyatelnosti (In Russ.)

16. Serikova V.E. [Analyzing the current situation in Russia's housing and utilities sector]. Molodoi uchenyi = Young Scientist, 2018, no. 18, pp. 368-371. URL: https://moluch.ru/archive/204/50070/ (In Russ.)

17. Smirnova Yu.O., Bibilashvili A.D. [Energy efficiency in housing and communal services]. Obrazovanie i nauka v sovremennom mire. Innovatsii $=$ Education and Science in Contemporary World. Innovation, 2017, no. 1, pp. 242-250. (In Russ.)

18. Shabalin E.M., Karp M.V. [Myths of reliable assessment of Russian enterprises' financial standing]. Finansy $i$ kredit $=$ Finance and Credit, 2012, no. 17, pp. 30-34.

URL: https://cyberleninka.ru/article/n/mify-realnoy-otsenki-finansovogo-sostoyaniya-rossiyskihpredpriyatiy (In Russ.)

19. Kameneva E.A., Shokhin E.I. [Financial mechanism of increase of energy efficiency and financial stability of managing organizations of housing and communal services of Russia]. Finansy $i$ kredit = Finance and Credit, 2013, no. 26, pp. 9-15. URL: https://cyberleninka.ru/article/v/finansovyymehanizm-povysheniya-energoeffektivnosti-i-finansovaya-ustoychivost-upravlyayuschihorganizatsiy-zhilischno (In Russ.)

\section{Conflict-of-interest notification}

We, the authors of this article, bindingly and explicitly declare of the partial and total lack of actual or potential conflict of interest with any other third party whatsoever, which may arise as a result of the publication of this article. This statement relates to the study, data collection and interpretation, writing and preparation of the article, and the decision to submit the manuscript for publication. 